\title{
Editorial: An attack on small business pension plans
}

The author is a pension consultant in the USA who works primarily with small businesses in designing retirement plans. Recently, the US Treasury Department and Internal Revenue Service have expressed their concern about the growth of a relatively new retirement design called New Comparability. These two groups are proposing to curtail these plans. The proposals will harm the growth of retirement plans for small businesses.

The case described below is not atypical. 'Bob' has a small manufacturing firm in Southeastern Wisconsin. He was 'downsized' from an engineering job at a large Fortune 500 manufacturing firm in the late '80s. Since that time, he has started his own business, and has built it from scratch into a business employing nearly 20 people.

At the time the author met Bob in 1993, he and his financial advisor were very concerned about adequate retirement benefits for him. He had invested his life savings in the business and had just finished putting his children through school. He had no retirement savings to speak of. We sat down and talked about providing retirement benefits for Bob and his three employees. He had had a fairly profitable year and was willing to contribute about $\$ 24,000$ for himself and his three employees.

The author discussed the following four options with him:
1 Defined Benefit Plan. A traditional defined benefit plan would provide Bob and his employees with considerable benefit security. However, making a commitment to contribute $\$ 24,000$ per year or about 15 per cent of total payroll was not a commitment that Bob was prepared to make.

\section{Simplified Employee Pension}

Plan (SEP). This relatively simple plan would permit Bob to deposit a flexible percentage of pay each year directly to an employee's IRA. Bob liked this flexibility, but decided that the SEP was not the desirable plan for two reasons: the employee would have immediate access to the money and his share of the $\$ 24,000$ contribution would be about 55 per cent, or about $\$ 13,500$ on a salary of $\$ 90,000$.

3 New Comparability Plan. This relatively new design (at the time) looked more attractive to Bob. $\mathrm{He}$ would receive a 78 per cent share of the contribution, or about $\$ 19,000$. His three employees would each receive a contribution equal to 7.5 per cent of pay.

4 Pay Bob a Bonus. The reality of the issue is that Bob could take the entire $\$ 24,000$ and pay himself a bonus of $\$ 24,000$. Assuming that he is in a 33 per cent tax bracket (federal and state), he would take home about $\$ 18,000$. 
Bob chose to create a new comparability plan. He has had good years and bad years. In the bad years, he has not contributed anything for himself or his employees.

In 1999, Bob had a great year and contributed the maximum allowable amount of $\$ 42,000$. He received a $\$ 27,000$ contribution as his share, or about 64 per cent of the total. His other seven eligible employees received an allocation of 8.5 per cent of pay.

Two of his three original employees are still working for Bob. One has an account balance of $\$ 8,800$ and the other about $\$ 6,000$. Bob has been able to save $\$ 90,000$ thus far, but he will need to save quite a bit more for a comfortable retirement.

Is this a discriminatory plan? Absolutely not. It complies with the regulations promulgated by Treasury and meets both the spirit and the letter of the law.

What happens if Treasury takes this plan away, as they proposed to do recently? The simple fact of the matter is that Bob will not have a plan. He will simply pay the bonus to himself and leave his employees to fend for themselves at retirement.

Bob's response to this Treasury initiative is very similar to that of other small businesses. In a survey conducted in the spring of 2000 by the American Society of Pension Actuaries (ASPA), it was found that there are over 10,000 new comparability plans adopted by small US businesses. In 58 per cent of cases, the small business had not previously provided a retirement plan for its employees. In an additional 20 per cent of cases, the small business had only a 401(k) plan funded by employee contributions and a company matching contribution.

An astonishing 50 per cent of the respondents in the survey stated that the small businesses would not adopt another retirement plan if new comparability plans were not permitted.

ASPA and the small business community in the USA are working hard to assure that the retirement security of thousands of US employees working for small businesses is not undermined by this Treasury initiative. It makes little sense to discourage small business from adopting or continuing retirement plans at the same time that the USA is trying to reduce the individual's reliance on Social Security and other public programmes.

Joan Gucciardi
Wauwatosa, Wisconsin
United States

